\title{
A Penis-shortening Device Described by the 13th Century Poet Rumi
}

\author{
C. W. Moeliker
}

Published online: 21 August 2007

(C) Springer Science+Business Media, LLC 2007

With great interest, I read Kompanje's (2006) clinical case report about a remarkable penis-shortening device invented in 1593 by the surgeon Hildanus. With this letter, I want to point your readers to an even older description of a similar device — not by a medical scholar, but by the great Persian humanist, philosopher, and poet Jalal-ud-Din Muhammad Rumi (1207-1273). In his poem, "The Importance of Gourdcrafting," Rumi vividly describes the sexual interactions between a women and a donkey. I cite here from Barks' (1995) translation:

There was a maidservant

who had cleverly trained a donkey

to perform the services of a man.

From a gourd,

she had carved a flanged device

to fit on the donkey's penis,

to keep him from going too far into her.

She had fashioned it just to the point

for her pleasure, and she greatly enjoyed

the arrangement, as often as she could!

The poem continues with the maidservant's mistress who "peeked through a crack in the door and saw the animal's marvelous member and the delight of the girl" and joins with the donkey, ignoring the advice of her servant to use the gourd:

Her fire kindled more,

and the donkey politely pushed as she urged him to, pushed through and into her intestines, and without a word, she died.

The carved gourd described by Rumi obviously has the same purpose as the device invented by Hildanus: preventing damage by too deep penetration during coitus. Both authors had a different reason to publish though. Hildanus' goal was purely medical, whereas Rumi teaches us two moral lessons: "Don't sacrifice your life to your animal soul" and "Don't open your shop before a Master taught you the craft." Rumi was right and-three centuries later-might even have inspired Hildanus to craft his remarkable penis-shortening device.

\section{References}

Barks, C. (1995). The essential Rumi. Edison, NJ: Castle Books. Kompanje, E. J. O. (2006). Painful sexual intercourse caused by a disproportionately long penis: An historical note on a remarkable treatment devised by Guilhelmus Fabricius Hildanus (1563-1643). Archives of Sexual Behavior, 35, 603-605.
C. W. Moeliker $(\square)$

Natural History Museum Rotterdam,

Westzeedijk 345 (Museumpark),

3015 AA Rotterdam,

The Netherlands

e-mail: moeliker@nmr.nl 